\title{
Long-term negative phosphorus budgets in organic crop rotations deplete plant-available phosphorus from soil
}

\author{
Magdalena Ohm ${ }^{1}$ - Hans Marten Paulsen ${ }^{1}$ - Jan Hendrik Moos ${ }^{1}$. \\ Bettina Eichler-Löbermann ${ }^{2}$
}

Accepted: 20 April 2017 /Published online: 17 May 2017

(C) INRA and Springer-Verlag France 2017

\begin{abstract}
In organic farming, phosphorus (P) can be imported in mineral form with rock phosphate, feedstuff for livestock or suitable organic fertilizers. Many organic farmers, however, rely on biological activation of soil $\mathrm{P}$ reserves and tolerate $\mathrm{P}$ deficits, not knowing when soil reserves will be depleted. We hypothesized that under conditions of a long-term negative $\mathrm{P}$ budget in organic farming, the decline in readily available soil $\mathrm{P}$ pools would be less pronounced in dairy systems (arable land and grassland) than in stockless systems (arable land), due to higher shares of forage legumes in crop rotations, longer plant soil coverage, and manure backflow. From 2001 to 2013, we analyzed those systems on one site in North Germany. We assessed topsoil for plant-available soil P concentration $[\mathrm{P}(\mathrm{CAL})]$, mineral soil P fractions (Hedley), organic $\mathrm{P}$, acid and alkaline phosphatase, and microbial activity (dehydrogenase). We measured $\mathrm{P}(\mathrm{CAL})$ each year on all fields of the crop rotations and grassland. The other soil characteristics were determined only in selected fields in 2001, 2009, and 2013. We observed that in grassland, all mineral P fractions, organic $\mathrm{P}$ contents, and microbial activity were considerably higher than in arable fields. On average, soil $\mathrm{P}(\mathrm{CAL})$ content decreased significantly in all systems (stockless arable -1.71 , dairy arable -1.41 , grassland $-3.18 \mathrm{mg} \mathrm{P} \mathrm{kg}^{-1}$ year ${ }^{-1}$ ), but the soil threshold value deemed to be sufficient for P supply $\left(>44 \mathrm{mg} \mathrm{kg}^{-1}\right.$ ) was preserved. The readily available inorganic $\mathrm{P}$ fractions $\left(\mathrm{H}_{2} \mathrm{O}-\mathrm{P}, \mathrm{NaHCO}_{3}-\mathrm{P}\right)$ were also lower in 2013 than
\end{abstract}

Hans Marten Paulsen

hans.paulsen@thuenen.de

1 Thünen-Institute of Organic Farming, Trenthorst 32, 23847 Westerau, Germany

2 Chair of Agronomy, University of Rostock, Justus von Liebig Weg 6, 18059 Rostock, Germany in 2001. Our data does not support a different development in either arable system. We could show that higher shares of forage legumes and manure recycling in an organic mixed arable dairy crop rotation and grassland do not necessarily mitigate decreases of plant-available P contents in soil as compared to a stockless system.

Keywords Nutrient management · Organic farming · Organic fertilization · Cropping system · Crop rotation and management $\cdot$ Grassland $\cdot \mathrm{P}$ budgets

\section{Introduction}

Soil persists as a temporal reservoir for phosphorus $(\mathrm{P})$ in plant production, but only a relatively small fraction of total soil $\mathrm{P}$ is available for direct plant or microbial uptake. Inorganic and organic $\mathrm{P}$ forms in soils are a result of multifaceted $\mathrm{P}$ turnover processes which are affected by plants, microorganisms, and abiotic factors (Annaheim et al. 2013). As in organic farming crops are to be nourished primarily through the soil ecosystem (Council Regulation (EC) No 834/2007 on Organic Production), the farmers should contribute to maintaining and enhancing soil fertility. In organic farming, the recycling of wastes and by-products of plant and animal production (e.g., livestock manures, compost) and low soluble mineral fertilizers (e.g., rock phosphates) are permitted for $\mathrm{P}$ import. Furthermore, organic farmers try to foster biological processes in the soil for $\mathrm{P}$ mobilization by diverse crop rotations and organic fertilization. Nevertheless, many of them tolerate $\mathrm{P}$ budget deficits not knowing when soil reserves will be depleted (Gosling and Shepherd 2005). In organic agricultural soils in Europe, $\mathrm{P}$ is often enriched due to former application of inorganic and organic fertilizers (Tóth et al. 2014). This offers reserves for organic farms with low external feed 
and fertilizer import. But, continuous $\mathrm{P}$ budget deficits may lead to low plant-available $\mathrm{P}$ contents in soil.

The availability of $\mathrm{P}$ in soil depends on the $\mathrm{P}$ input and is also regulated by biological and biochemical processes. The biological oxidation of organic $\mathrm{P}$ in soil is largely mediated by microbial activity and by phosphatases of either plant or microbial origin, whereas the mobilization of less-available inorganic P sources is supported by, e.g., root-induced acidification in the rhizosphere and excretion of organic acids (Hinsinger 2001; Richardson et al. 2011). The application of organic matter can improve soil chemical and physical properties as well as the nutrient availability in soil (Manlay et al. 2007). On the other hand, the amount and quality of the organic matter supplied, mainly its C:N:P ratio, also affect the soil microbial activity (Güsewell and Gessner 2009). Increasing contents of inorganic $P$ in soil can reduce or mask $P$ mobilization processes and may also reduce the excretion of phosphatases and, as a consequence, the hydrolyzation of organic P compounds (Dick et al. 2011).

Worldwide, the recommended extraction procedures for the determination of plant-available $\mathrm{P}$ in soil differ but fertilizer recommendations were usually given with special attention to soil inorganic P pools (Jordan-Meille et al. 2012). However, organic $\mathrm{P}$ constitutes an important proportion of total $\mathrm{P}$ in soil of up to 94\% (Achat et al. 2009). The soil organic P fraction includes different chemical forms which differ in their potential availability for plants (Annaheim et al. 2013). Especially in grazed pastures, organic $\mathrm{P}$ is seen as an important source to sustain the $\mathrm{P}$ nutrition of plants, but quantitative data on the release of orthophosphate are widely missing (Nash et al. 2014).

In general, legume species were often described to mobilize poorly available $\mathrm{P}$ forms, mainly due to the exudation of organic acids, ions, and phosphatases (Li et al. 2007). The cultivation of legumes in crop rotations is therefore, besides being an important source of $\mathrm{N}$, seen as a good opportunity to utilize soil $\mathrm{P}$ reserves.

Against this background, we expected that the soil P availability and enzymatic activity would behave differently in dependence of the farming systems over the study period. We hypothesized that under conditions of long-term negative $\mathrm{P}$ budget in organic farming, the decline in readily available soil $\mathrm{P}$ pools would be less pronounced in a dairy system (arable land and grassland) than in a stockless system (arable land). We believe this was due to the manure backflow to fields, the higher percentages of forage legumes, and longer soil cover during the year in the dairy systems.

\section{Material and methods}

\subsection{Study site}

The study on arable and grassland fields was undertaken at the organic experimental station of the Thünen-Institute of
Organic Farming in Trenthorst/Wulmenau in North Germany $\left(53^{\circ} 46^{\prime} \mathrm{N}, 10^{\circ} 31^{\prime} \mathrm{E}\right.$, average precipitation $706 \mathrm{~mm}$ year $^{-1}$, mean temperature $8.8^{\circ} \mathrm{C}$ ) which was converted to organic farming in 2001. No mineral or imported organic $P$ fertilizers were applied since then. The soils were characterized as Cambisols and Luvisols from boulder clay with sandy loamy texture (means: arable land $46 \%$ sand, $34 \%$ silt, $18 \%$ clay; grassland $38 \%$ sand, $41 \%$ silt, $16 \%$ clay).

Former conventional crop rotations were focused on winter cereals and rapeseed production ( $\mathrm{N}$ fertilization level 200 $250 \mathrm{~kg} \mathrm{ha}^{-1}$ year $^{-1}$, dry matter grain yields $8-10 \mathrm{t} \mathrm{ha}^{-1}$ and 3-4.5 $\mathrm{t} \mathrm{ha}^{-1}$, respectively). In 2001/2002, soil fertility was strengthened by introducing clover varieties for biological $\mathrm{N}$ fixation before the experimental farm was divided into different organic farming systems with fixed field size and positions in 2002/2003. In our study, adjacent fields of a stockless and a mixed dairy system were analyzed. These arable systems had a 6-year crop rotation on six fields, but differed in input of livestock manure, crops, and percentage of forage legumes and grain legumes (Table 1). Permanent grassland was additionally used as feed resource in the dairy system (Fig. 1). Here, mineral fertilization was omitted and organic fertilization was reduced with conversion to organic farming. A 1-ha long-term monitoring plot (LTM plot) with four georeferenced sampling points (LTM points) was located within each field. The LTM points had a distance of $>30-60 \mathrm{~m}$ and were used for regular soil and plant sampling. In the following, results of long-term development of plant-available $\mathrm{P}(\mathrm{CAL})$ in soil were based on analysis of data from samples of all LTM points in all LTM plots of all years. For detailed analyses of P fractions, organic P, and enzymatic activity in soils, we focused on LTM points of four LTM plots (Fig. 2, focus areas). Average values of other chemical topsoil properties $(\mathrm{C}, \mathrm{N}, \mathrm{K}, \mathrm{Mg}, \mathrm{pH})$ in February 2003 and in February 2013 (winter season) are given in Table 1 to show the general trends in development over time.

In the stockless system, grains were exported and clover mulch and straw always remained on the fields. No organic or mineral fertilizers were applied to this system during 20012013. In the dairy system, clover grass and straw were used as forage and litter in the stable, and solid and liquid manures were applied to arable land and grassland according to the management scheme of the farm. In the fields we focused on, manure was applied in 2004, 2005, 2007, and 2010 on arable land and in $2005,2007,2009$, and 2012 on grassland. The chemical composition of the manure was not recorded continuously, but in the period 2010 to $2012,5.3 \mathrm{~kg} \mathrm{P} \mathrm{ha}^{-1}$ year $^{-1}$ and $1.4 \mathrm{~kg} \mathrm{P} \mathrm{ha}{ }^{-1}$ year $^{-1}$ have been applied on arable land and grassland of the dairy farm, respectively (Ohm et al. 2015). Grassland was grazed and harvested for silage and hay. Feedstuff imports did not balance out the field and farm P budgets of the mixed dairy system. In a close view, arable and grassland fields of the dairy system had P deficits of -10.9 
Table 1 Crops grown in the focus areas within the arable crop rotations in Trenthorst (harvest years 2001-2013), main sward components in the focus areas of grassland and average values for main soil chemical parameters in 2003 and 2013 (per year $\mathrm{n}=24$ for arable crop rotations, $0-30 \mathrm{~cm}$ sampling depth, and $\mathrm{n}=8$ for grassland, $0-10 \mathrm{~cm}$ sampling depth); \pm values indicate standard errors

\begin{tabular}{|c|c|c|c|c|c|c|c|c|c|}
\hline Year & \multicolumn{3}{|l|}{ Stockless } & \multicolumn{3}{|c|}{$\begin{array}{l}\text { Farming systems } \\
\text { Dairy }\end{array}$} & \multicolumn{3}{|c|}{ Permanent grassland } \\
\hline 2001 & \multicolumn{3}{|c|}{$\begin{array}{l}\text { Winter oilseed rape } \\
\text { (Brassica napus) }\end{array}$} & \multicolumn{3}{|c|}{ Winter oilseed rape } & \multirow{13}{*}{\multicolumn{3}{|c|}{$\begin{array}{l}\text { Sward intact for decades containing a mixture of } \\
\text { grasses (e.g., Lolium perenne, Festuca pratensis, } \\
\text { Dactylis glomerata) legumes (mostly Trifolium } \\
\text { repens), and herbaceous plants (e.g., Taraxacum } \\
\text { officinale, Ranunculus, Carduus, Stellaria media, } \\
\text { Rumex) }\end{array}$}} \\
\hline 2002 & \multicolumn{3}{|c|}{$\begin{array}{l}\text { White clover } \\
\text { (Trifolium pratense) }\end{array}$} & \multicolumn{3}{|c|}{$\begin{array}{l}\text { Red clover grass (Lolium perenne, } \\
\text { Phleum pratense, Trifolium } \\
\text { pratense) }\end{array}$} & & & \\
\hline 2003 & \multicolumn{3}{|c|}{$\begin{array}{l}\text { Winter wheat } \\
\text { (Triticum aestivum) }\end{array}$} & \multicolumn{3}{|c|}{ Red clover grass } & & & \\
\hline 2004 & \multicolumn{3}{|c|}{ Oats (Avena sativa) } & \multicolumn{3}{|c|}{ Winter wheat } & & & \\
\hline 2005 & \multicolumn{3}{|c|}{ Field pea (Pisum sativum) } & \multicolumn{3}{|c|}{ Faba bean $($ Vicia faba $)+$ oats } & & & \\
\hline 2006 & \multicolumn{3}{|c|}{ Winter oilseed rape } & \multicolumn{3}{|c|}{ Field pea + spring barley } & & & \\
\hline 2007 & \multicolumn{3}{|c|}{$\begin{array}{l}\text { Triticale (Triticosecale) }+ \text { red } \\
\quad \text { clover }\end{array}$} & \multicolumn{3}{|c|}{ Triticale + red clover grass } & & & \\
\hline 2008 & \multicolumn{3}{|c|}{ Red clover } & \multicolumn{3}{|c|}{ Red clover grass } & & & \\
\hline 2009 & \multicolumn{3}{|c|}{ Winter wheat } & \multicolumn{3}{|c|}{ Red clover grass } & & & \\
\hline 2010 & \multicolumn{3}{|c|}{$\begin{array}{l}\text { Spring barley } \\
\text { (Hordeum vulgare) }\end{array}$} & \multicolumn{3}{|c|}{ Maize (Zea mays) } & & & \\
\hline 2011 & \multicolumn{3}{|c|}{ Field pea } & \multicolumn{3}{|c|}{ Winter wheat } & & & \\
\hline 2012 & \multicolumn{3}{|c|}{ Winter oil seed rape } & \multicolumn{3}{|l|}{ Faba bean } & & & \\
\hline 2013 & \multicolumn{3}{|c|}{ Triticale + red clover } & \multicolumn{3}{|c|}{ Triticale + red clover grass } & & & \\
\hline \multicolumn{10}{|l|}{ Soil chemical parameters } \\
\hline Year & 2003 & 2013 & & 2003 & 2013 & & 2003 & 2013 & \\
\hline $\mathrm{pH}$ & $6.9 \pm 0.04$ & $6.6 \pm 0.05$ & $* * *$ & $6.7 \pm 0.04$ & $6.5 \pm 0.05$ & $* *$ & $5.5 \pm 0.05$ & $5.5 \pm 0.05$ & n.s. \\
\hline Organic $\mathrm{C}\left[\mathrm{g} \mathrm{kg}^{-1}\right]$ & $13.9 \pm 0.4$ & $12.7 \pm 0.4$ & $*$ & $14.0 \pm 1.1$ & $12.7 \pm 0.3$ & n.s. & $35.5 \pm 1.9$ & $23.9 \pm 2.5$ & $* *$ \\
\hline Total $\mathrm{N}\left[\mathrm{g} \mathrm{kg}^{-1}\right]$ & $1.4 \pm 0.05$ & $1.2 \pm 0.04$ & $* *$ & $1.4 \pm 0.11$ & $1.2 \pm 0.03$ & n.s. & $3.6 \pm 0.2$ & $2.3 \pm 0.2$ & $* * *$ \\
\hline $\mathrm{C}: \mathrm{N}$ & $10.3: 1$ & $10.8: 1$ & n.s. & $10.2: 1$ & $10.8: 1$ & $*$ & $9.8: 1$ & 10.4:1 & $*$ \\
\hline $\operatorname{Mg}\left(\mathrm{CaCl}_{2}\right)\left[\mathrm{mg} \mathrm{kg}^{-1}\right]$ & $196 \pm 11$ & $110 \pm 4$ & $* * *$ & $181 \pm 14$ & $105 \pm 4$ & $* * *$ & $339 \pm 24$ & $199 \pm 7$ & $* * *$ \\
\hline $\mathrm{K}(\mathrm{CAL})\left[\mathrm{mg} \mathrm{kg}^{-1}\right]$ & $151 \pm 6$ & $101 \pm 4$ & $* * *$ & $136 \pm 6$ & $112 \pm 4$ & $* *$ & $228 \pm 46$ & $194 \pm 28$ & n.s. \\
\hline
\end{tabular}

Comparison of values in 2003 and 2013, paired $t$ test or paired Wilcoxon rank sum test $p \leq 0.001^{* * *}, 0.001<p \leq 0.01^{* *}, 0.01<p \leq 0.05^{*}, p>0.05$ n.s. not significant

and $-7.9 \mathrm{~kg} \mathrm{P} \mathrm{ha}^{-1}$ year $^{-1}$ in that time, respectively (Ohm et al. 2015). In the dairy arable system, average grain yields of legumes and cereals were between 2.5 and $5 \mathrm{t} \mathrm{ha}^{-1}$ dry matter.
Average dry matter yields of maize and grass-clover (2-3 cuts) for silage preparation were between 7.7 and $11 \mathrm{t} \mathrm{ha}^{-1}$. Grassland yields with grazing and harvesting were determined
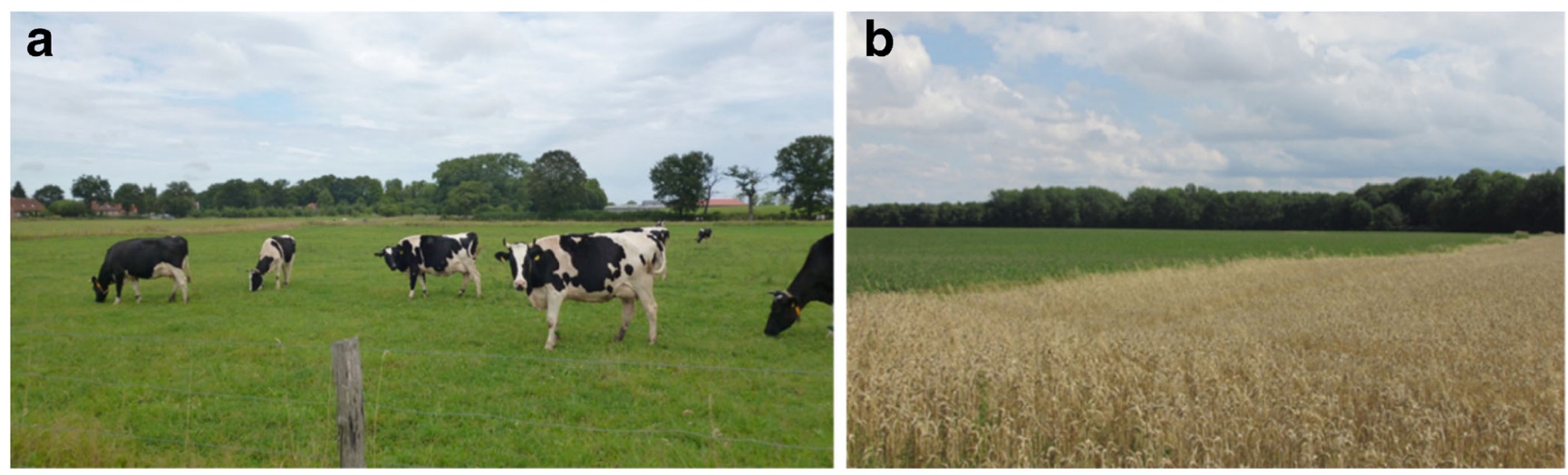

Fig. 1 View of fields included in the study on long-term organic farming systems in Trenthorst/Wulmenau (North Germany). a Permanent grassland grazed by cows and harvested since year $<1950$
(54 ha). b Arable land divided into a stockless system without external $\mathrm{P}$ input ( 30 ha) and a dairy system with internal $\mathrm{P}$ backflow via manure (62 ha) since year 2001 
Fig. 2 Map showing the fields of arable land (dairy and stockless) and grassland at the organic experimental station Trenthorst/ Wulmenau, with long-term monitoring (LTM) plots for soil sampling and analysis. Four LTM plots were chosen as focus areas (asterisk) for detailed studies of soil $\mathrm{P}$ characteristics

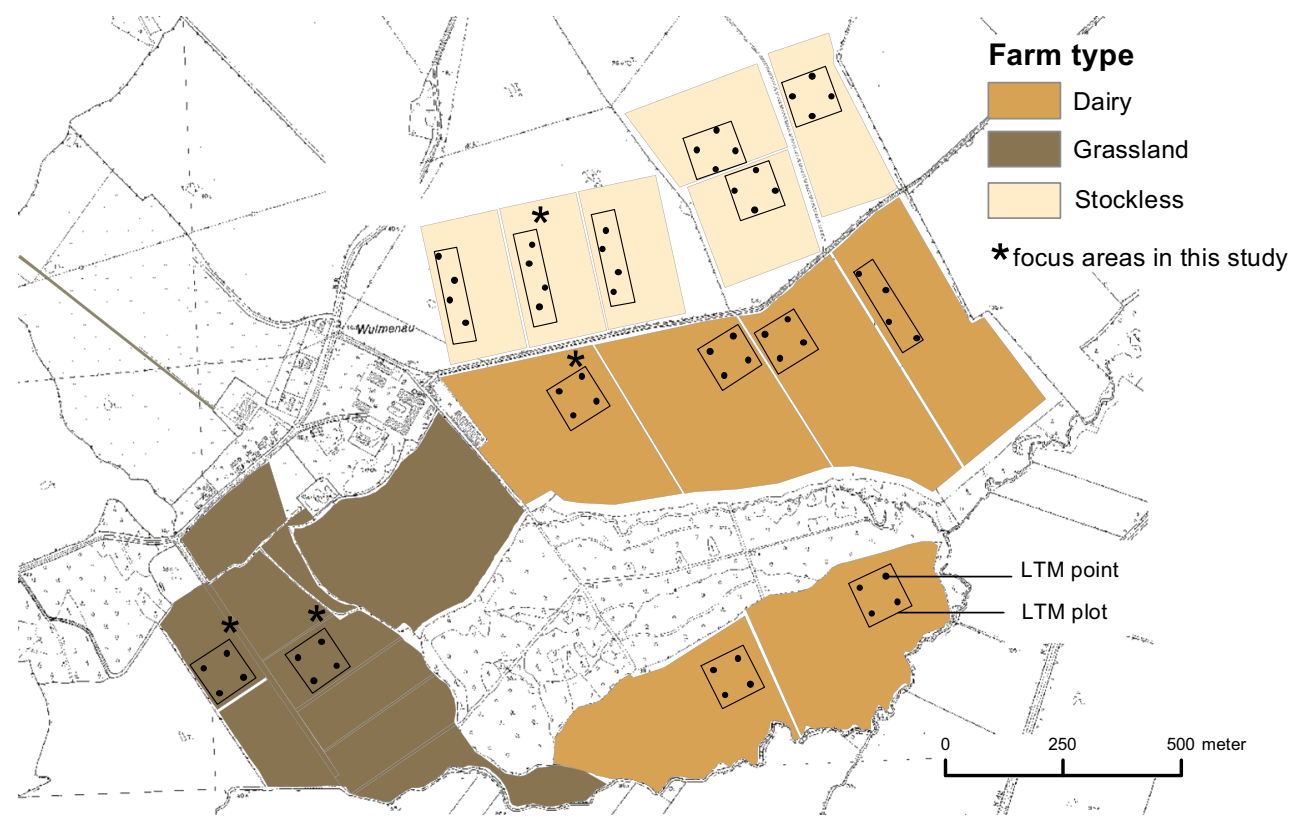

to be between 4 and $6 \mathrm{t} \mathrm{ha}^{-1}$ year ${ }^{-1}$ in that time. Also, the stockless system was in a continuous $\mathrm{P}$ export situation since 2001. Here, an average dry matter grain yield level of $2 \mathrm{t} \mathrm{ha}^{-1}$ year $^{-1}$ (dry matter grain yields of rapeseed, legumes, or cereals between 1 and $5 \mathrm{tha}^{-1}$ ) with mean $\mathrm{P}$ concentrations in grains of $3.5 \mathrm{~g} \mathrm{P} \mathrm{kg}^{-1}$ (typical P contents 2.8 and $6.8 \mathrm{~g} \mathrm{~kg}^{-1}$ in cereal and legume grains, respectively) in 10 of 13 harvest years on six fields meant an average field budget deficit of $-5.4 \mathrm{~kg} \mathrm{P} \mathrm{ha}{ }^{-1}$ year $^{-1}$.

\subsection{Soil sampling}

Soil samples to determine enzyme activities were collected from three drillings of $4 \mathrm{~cm}$ diameter with a depth of $30 \mathrm{~cm}$ around each LTM point in the focus areas in May 2001 and again in May 2013 (spring season). These samples were stored frozen at -70 and $-20^{\circ} \mathrm{C}$, respectively. Also, various inorganic $\mathrm{P}$ forms, organic $\mathrm{P}$ and total $\mathrm{P}$ were analyzed, this additionally in soil sampled on arable land in February 2009 and stored frozen at $-20{ }^{\circ} \mathrm{C}$. Changes over time in plantavailable $\mathrm{P}(\mathrm{CAL})$ were described by annual sampling during 2001-2013 in arable land and from 2003 to 2013 in grassland. These samples were collected in February or March (winter season) of each year on all 14 LTM plots of the long-term monitoring scheme (Fig. 2). The sampling depth for these samples was $0-30 \mathrm{~cm}$ in arable land and $0-10 \mathrm{~cm}$ in grassland.

\subsection{Soil and plant analyses}

In soils, the concentrations of biochemical indicators for $\mathrm{P}$ mobilization (acid and alkaline phosphatases), of microbial activity (dehydrogenases), of the $\mathrm{P}$ availability to plants
$(\mathrm{P}(\mathrm{CAL}))$, of mineral $\mathrm{P}$ fractions, of organic $\mathrm{P}$, and of total $\mathrm{P}$ were evaluated.

For the enzymatic analyses, the frozen soil samples were thawed and kept at room temperature for $24 \mathrm{~h}$. Roots were removed by tweezers before chemical extraction. The acid and alkaline phosphatase activities were determined after incubating $1 \mathrm{~g}$ soil with p-nitrophenolphosphate for $1 \mathrm{~h}$ at $37^{\circ} \mathrm{C}$ at a $\mathrm{pH}$ of either 6.5 (acid phosphatase) or 11.0 (alkaline phosphatase) by photometrical measurement of the p-nitrophenol ( $p$ $\mathrm{NP}$ ), which was extracted with $1 \mathrm{M} \mathrm{CaCl}_{2}$ and $0.5 \mathrm{M} \mathrm{NaOH}$, respectively (Tabatabai and Bremner 1969). The dehydrogenase activity was analyzed according to Thalmann (1968) by suspending $1 \mathrm{~g}$ soil in $0.8 \%$ triphenyltetrazolium chloride (TTC) solution followed by incubation at $37{ }^{\circ} \mathrm{C}$ for $24 \mathrm{~h}$. TTC will be reduced to triphenylformazan (TPF) by most microorganisms. The released TPF was extracted with acetone and measured photometrically at $546 \mathrm{~nm}$. The other parameters were determined in air-dried soil samples. The plantavailable soil $P$ concentration was extracted with calcium acetate lactate as P(CAL) (Schüller 1969), which is a standard soil $\mathrm{P}$ test in Germany. To characterize the inorganic soil $\mathrm{P}$ forms in more detail, a modified sequential $\mathrm{P}$ fractionation method was applied in accordance with Hedley et al. (1982). The most labile $\mathrm{P}$ fractions were removed with mild extractants, followed by increasingly stronger extractants to identify less biologically available fractions. The following inorganic $\mathrm{P}$ fractions with decreasing solubility were derived stepwise $\mathrm{H}_{2} \mathrm{O}-\mathrm{P}>\mathrm{NaHCO}_{3}-\mathrm{P}>\mathrm{NaOH}-\mathrm{P}>\mathrm{HCl}-\mathrm{P}>$ Residual P. Residual $\mathrm{P}$ after $\mathrm{HCl}$ extraction and total $\mathrm{P}$ in the original soil sample were extracted from the soil by $18 \mathrm{M} \mathrm{H}_{2} \mathrm{SO}_{4}$ and the following addition of $\mathrm{H}_{2} \mathrm{O}_{2}(30 \%)$ (Tiessen et al. 1993). To estimate the organic $\mathrm{P}$ concentration in soil (Porg), $10 \mathrm{~g}$ of dry soil were treated for $16 \mathrm{~h}$ with $0.25 \mathrm{M} \mathrm{NaOH}-0.05 \mathrm{M} \mathrm{Na}_{2^{-}}$ 
EDTA in a soil-to-solution ratio of $1: 10(w: v)$. For inorganic $P$, the extracts were diluted 10 times before colorimetric measurement with malachite green at $623 \mathrm{~nm}$ (Ohno and Zibilske 1991). For total $\mathrm{P}$ in the $\mathrm{NaOH}-\mathrm{EDTA}$ extract, a persulfate digestion was performed with $1 \mathrm{~mL}$ of $\mathrm{NaOH}$ EDTA extracts and $10 \mathrm{~mL}$ of digestion mix $\left(6 \mathrm{~g} \mathrm{NH}_{4}\right.$-persulfate in $100 \mathrm{~mL} 0.9 \mathrm{M} \mathrm{H}_{2} \mathrm{SO}_{4}$ ). In the neutralized digests, total $\mathrm{P}$ was determined by colorimetric measurement. Organic P was calculated as the difference between total $\mathrm{P}$ and inorganic P. Total $\mathrm{P}$ in plant material was determined photometrically after nitric acid digestion in a microwave oven (Huang et al. 2004).

\subsection{Statistical analysis}

Statistical analyses were conducted using R 3.2.2. Results on $\mathrm{P}$ fractions, total $\mathrm{P}$, Porg, and activity of phosphatases and dehydrogenases from the focus areas of 2001, 2009, and 2013 were compared by pairwise $t$ tests or, if data were not normally distributed, with the paired Wilcoxon signed-ranks test. The development of soil $\mathrm{P}(\mathrm{CAL})$ concentrations between 2001 and 2013 was analyzed using linear mixed-effects models. As the data were not normally distributed, they were log-transformed. For the data from arable land (dairy and stockless), the model was set up with year, farming system, and the interaction of these two as fixed effects and LTM point nested within LTM plot (see Fig. 2) and crop (Table 1) as random intercept effects. The model for the grassland data used year as fixed effect and LTM point nested within LTM plot as random intercept effect. The $\mathrm{R}$ package lme4 ( $\mathrm{R}$ package version 1.1-8) was used for the modeling of mixed effects. Marginal and conditional $R^{2}$ were calculated for the mixed models by using the function r.squaredGLMM from the $\mathrm{R}$ package MuMIn (R package 1.15.1). While marginal $R^{2}$ deals with the variance explained by the fixed factors, conditional $R^{2}$ deals with the variance explained by the entire model (fixed + random factors). Least-square means (LS-means) were extracted after modeling using $\mathrm{R}$ package LS-means. A linear regression was performed based on LS-means for analysis of the development of $\mathrm{P}(\mathrm{CAL})$ over years in the farming systems. Possible relations between $\mathrm{P}$ in plants and $\mathrm{P}(\mathrm{CAL})$ in soils were analyzed by the Spearman rank correlation.

\section{Results and discussion}

To test the hypothesis, we compared the development of the soil characteristics in the three farming systems: two arable systems (dairy and stockless) and a grassland system from 2001 to 2013. We expected stronger reductions of soil P concentrations and lower microbial activities in the stockless arable system than in the other tested systems.

\section{1 $\mathrm{P}(\mathrm{CAL})$ contents in soil}

The mixed models for arable land and grassland had a marginal $R^{2}$ of 0.21 and 0.52 and conditional $R^{2}$ of 0.69 and 0.60 , respectively. There are relatively high explanation rates of the variance with the entire models for arable land and grassland, whereas the different marginal $R^{2}$ indicate a higher explanation rate of the fixed effect (year) in grassland compared to the fixed effects (year, farming system) used in the model approach for arable land. Maybe this effect was due to higher variability of crops and to soil cultivation in arable systems compared to the continuous plant cover of soils in grassland.

Results from other long-term experiments with arable land (Tunney et al. 2003) and grassland (Messiga et al. 2015) have shown that plant-available soil test $\mathrm{P}$ is closely related to $\mathrm{P}$ budgets and that a single linear regression can describe changes in soil test $\mathrm{P}$ for both negative and positive $\mathrm{P}$ budgets. Also in all our systems we found a significant reduction of the $\mathrm{P}(\mathrm{CAL})$ values (Fig. 3) by linear regression. The average yearly reduction of the $\mathrm{P}(\mathrm{CAL})$ values was $1.76 \mathrm{mg} \mathrm{kg}^{-1}$ in the stockless arable plots, $1.41 \mathrm{mg} \mathrm{kg}^{-1}$ in the dairy arable plots, and $3.17 \mathrm{mg} \mathrm{kg}^{-1}$ in the grassland plots (Fig. 3).

Grassland had higher starting values in $\mathrm{P}(\mathrm{CAL})$ and higher data variability than arable land (Fig. 3). Higher variability could be an effect of excrements of grazing cattle in the soil top layer and also of missing soil tillage which would have eased distribution of $\mathrm{P}$ from organic matter from plant residues and organic fertilization in the arable systems. In another study soils that were high in $\mathrm{P}$ exhibited a faster change in soil test $\mathrm{P}$ because of the lower capacity to bind P (Zhan et al. 2015). Besides the initial $\mathrm{P}(\mathrm{CAL})$ values the relation between $\mathrm{P}$ budget and changes in soil test $\mathrm{P}$ depends also on the location, soil type and $\mathrm{pH}$ value (Messiga et al. 2015). As we compared fields from one location we can assume that differences in soil characteristics like $\mathrm{pH}$ and soil texture will be less relevant in arable land, whereas lower $\mathrm{pH}$ in grassland and permanent plant coverage might have led to different dynamics. Weather effects as reasons for different development could be almost excluded as the $\mathrm{P}(\mathrm{CAL})$ content in the grassland and the arable system did not show the same pattern over the years.

Looking at possible effects of different crops, relatively high values of the labile inorganic $P$ fractions were found after cultivation of legumes in arable land (Table 2) (see also Chapter 3.2). But neither the contents of the labile $\mathrm{P}$ fractions nor of $\mathrm{P}(\mathrm{CAL})$ contents in the focus areas of both rotations supported clear differences in development in both arable systems. With regard to the determination of labile $\mathrm{P}$ fractions, since only 3 years and a small number of samples were analyzed, possible effects of soil heterogeneity might have increased the variability of data. A more consistent trend could be derived from the higher number of data used for regression analysis of $\mathrm{P}(\mathrm{CAL})$ contents over all 12 years. Thus, to avoid 
$\mathbf{P}(\mathrm{CAL})\left[\mathrm{mg} \mathrm{kg}^{-1}\right]$

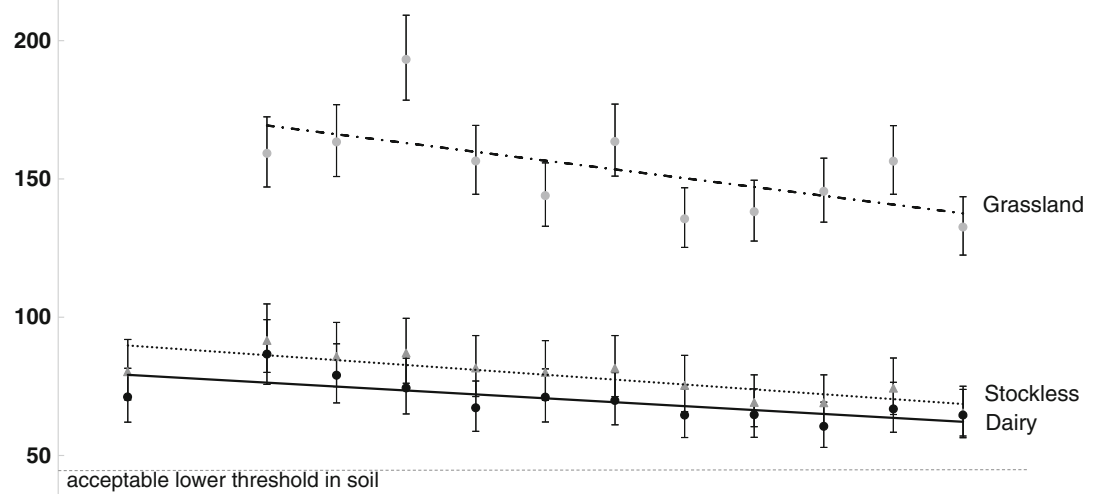

$\begin{array}{llllllllllllll}0 & 2001 & 2002 & 2003 & 2004 & 2005 & 2006 & 2007 & 2008 & 2009 & 2010 & 2011 & 2012 & 2013\end{array}$

Fig. 3 Development of plant-available $\mathrm{P}(\mathrm{CAL})$ values (LS-means) in soils over the years within the stockless and dairy farming system $(n=24$ per year and crop rotation, sampling depth: 0-30 cm, 2001, 2003-2013) and on grassland $(n=8$ per year, sampling depth: $0-10 \mathrm{~cm}, 2003-2013)$ and acceptable lower threshold according to Kuchenbuch and Buczko (2011).
A declining trend is visible in all three systems. Error bars indicate the 95\% confidence interval of the LS-means. Regression equations: Grassland: $\mathrm{y}=-3.177 x+172.48$, adj. $r^{2}=0.30, p=0.046$, Stockless arable: $y=-1.763 \times+91.5$, adj. $r^{2}=0.66, p=0.001$, Dairy arable: $y=-1.415 \times+$ $80.54, \operatorname{adj} . r^{2}=0.50, p=0.006$

utilization of $\mathrm{P}$ sources and the reduction of $\mathrm{P}$ losses in agroecosystems (Cordell et al. 2009). Similarly, Simpson et al. (2011) stated that managing soil fertility near the critical $\mathrm{P}$ level maximizes the $\mathrm{P}$ efficiency. So, mining $\mathrm{P}$ soil reserves as what happened in the systems of this study can replace the external P supply with fertilizers for a certain time span. However, in a long term, this practice is not sustainable and the $\mathrm{P}$ applications within a crop rotation should correspond to the $\mathrm{P}$ removal by crop harvests. For the grassland, however, the decrease of the relatively high initial soil $\mathrm{P}(\mathrm{CAL})$ values could have been useful to reach the range for the optimal $\mathrm{P}$ concentration and to reduce the risk of $\mathrm{P}$ losses.

\subsection{Hedley $P$ fractions and organic $P$ in soil}

The soil P fractions were analyzed in 2001, 2009, and 2013 and in the focus areas only. The values of the labile inorganic soil $\mathrm{P}$ fractions $\left(\mathrm{H}_{2} \mathrm{O}-\mathrm{P}, \mathrm{NaHCO}_{3}-\mathrm{P}\right)$ of the arable systems decreased during the study period, while significant reductions occurred mainly from 2009 to 2013 (Table 2). Concentrations of labile P pools in soils depend on many influencing factors (see above) and can vary widely in dependence of the field conditions (e.g., Messiga et al. 2015; Requejo and Eichler-Löbermann 2014), which underlines the importance of long-term studies with a dense sampling scheme. In this context, the $\mathrm{P}(\mathrm{CAL})$ values did not differ between each single year, although in the long term, a significant decrease of the $\mathrm{P}(\mathrm{CAL})$ values could be derived by regression (see above).

The labile $\mathrm{P}$ fractions in the arable soils after growing clover grass were relatively high in 2009. Forage legumes have a 
Table 2 Development of soil P characteristics (P fractions, and enzyme activity). Measurements are done at the same LTM-points in 2001, 2009, and 2013 at arable land and grassland in Trenthorst (arable land stockless: $n=4$, arable land dairy: $n=4$, grassland: $n=8,0-30 \mathrm{~cm}$ ).

\begin{tabular}{|c|c|c|c|c|c|c|c|c|c|c|c|}
\hline \multirow[t]{2}{*}{ Year } & \multirow[t]{2}{*}{ System } & \multicolumn{6}{|c|}{$P$ fractions $\left[\mathrm{mg} \mathrm{kg}^{-1}\right]$} & \multirow[t]{2}{*}{$\begin{array}{l}\text { Porg } \\
{\left[\mathrm{mg} \mathrm{kg}^{-1}\right]}\end{array}$} & \multicolumn{2}{|c|}{$\begin{array}{l}\text { Phosphatase activity } \\
{[\mu \mathrm{g} \text { p-NP g DM }} \\
\left.\text { soil }^{-1}\right]\end{array}$} & \multirow[t]{2}{*}{$\begin{array}{l}\text { Dehydrogenase } \\
{\left[\mu \mathrm{g} \text { TPF g DM soil }{ }^{-1}\right]}\end{array}$} \\
\hline & & $\mathrm{H}_{2} \mathrm{O}$ & $\mathrm{NaHCO}_{3}$ & $\mathrm{NaOH}$ & $\mathrm{HCl}$ & Residual & Total & & Alkaline & Acid & \\
\hline $2001^{1}$ & Stockless & $\mathbf{8 . 2 5} \pm 1.51$ & $\mathbf{4 3 . 6} \pm 4.97$ & $\mathbf{1 1 4} \pm 10.4$ & $\mathbf{1 0 3} \pm 17.8$ & $154 \pm 10.7$ & $444 \pm 42.8$ & $\mathbf{1 0 7} \pm 23.8$ & $139 \pm 5.87$ & $133 \pm 4.48$ & $\mathbf{4 0 . 6} \pm 7.49$ \\
\hline $2009^{2}$ & Stockless & $\mathbf{9 . 6 2} \pm 0.43$ & $\mathbf{5 9 . 0} \pm 4.95$ & $112 \pm 2.66$ & $113 \pm 12.3$ & $\mathbf{1 6 7} \pm 14.1$ & $461 \pm 38.1$ & $\mathbf{8 3 . 8} \pm 7.90$ & & & \\
\hline \multirow[t]{4}{*}{$2013^{3}$} & Stockless & $\mathbf{5 . 1 2} \pm 1.05$ & $37.9 \pm 2.77$ & $\mathbf{9 5 . 0} \pm 5.64$ & $\mathbf{1 1 5} \pm 13.7$ & $146 \pm 16.7$ & $\mathbf{5 3 2} \pm 33.5$ & $\mathbf{8 5 . 0} \pm 15.7$ & $\mathbf{1 4 2} \pm 2.26$ & $\mathbf{1 6 0} \pm 3.45$ & $33.9 \pm 3.45$ \\
\hline & $2001-2009$ & 0.377 & 0.066 & 0.898 & 0.191 & $0.043 *$ & 0.398 & 0.273 & 0.38 & $0.0002 * * *$ & 0.42 \\
\hline & $2001-2013$ & 0.056 & 0.130 & 0.202 & 0.217 & 0.400 & 0.73 & 0.093 & & & \\
\hline & $2009-2013$ & $0.013 *$ & $0.034^{*}$ & $0.033 *$ & 0.777 & 0.093 & $0.023 *$ & 0.892 & & & \\
\hline $2001^{1}$ & Dairy & $7.25 \pm 0.60$ & $\mathbf{4 1 . 0} \pm 4.41$ & $104 \pm 10.6$ & $\mathbf{9 7 . 6} \pm 20.9$ & $\mathbf{1 5 0} \pm 8.27$ & $479 \pm 68.3$ & $\mathbf{1 0 7 . 7} \pm 19.0$ & $\mathbf{1 5 1} \pm 0.68$ & $149 \pm 5.74$ & $\mathbf{1 8 . 4} \pm 2.47$ \\
\hline $2009^{2}$ & Dairy & $\mathbf{9 . 3 8} \pm 0.55$ & $\mathbf{3 9 . 1} \pm 2.70$ & $\mathbf{8 7 . 0} \pm 6.44$ & $133 \pm 20.2$ & $\mathbf{1 4 9} \pm 11.5$ & $\mathbf{5 4 4} \pm 33.3$ & $\mathbf{1 0 0 . 2} \pm 4.40$ & & & \\
\hline \multirow[t]{4}{*}{$2013^{3}$} & Dairy & $\mathbf{5 . 0 0} \pm 0.96$ & $\mathbf{3 0 . 9} \pm 2.58$ & $\mathbf{8 4 . 0} \pm 4.49$ & $\mathbf{1 0 1} \pm 15.6$ & $153 \pm 6.67$ & $498 \pm 18.6$ & $\mathbf{6 3 . 3} \pm 1.88$ & $\mathbf{1 5 6} \pm 0.91$ & $156 \pm 3.74$ & $\mathbf{2 7 . 3} \pm 1.07$ \\
\hline & $2001-2009$ & $0.007 * *$ & 0.649 & 0.215 & 0.236 & 0.962 & 0.317 & 0.652 & $0.026^{*}$ & 0.078 & 0.072 \\
\hline & $2001-2013$ & 0.093 & 0.111 & 0.206 & 0.806 & 0.521 & 0.776 & 0.100 & & & \\
\hline & $2009-2013$ & $0.033 *$ & $0.007 * *$ & 0.464 & 0.106 & 0.806 & 0.059 & $0.006 * *$ & & & \\
\hline 2001 & Grassland & $\mathbf{1 4 . 1} \pm 1.34$ & $\mathbf{1 7 0} \pm 9.31$ & $431 \pm 12.7$ & $195 \pm 23.0$ & $\mathbf{1 3 0} \pm 6.42$ & $1366 \pm 40.8$ & $\mathbf{6 7 5} \pm 33.3$ & $\mathbf{1 7 3} \pm 1.76$ & $176 \pm 3.32$ & $\mathbf{1 3 3} \pm 9.00$ \\
\hline \multirow[t]{2}{*}{2013} & Grassland & $\mathbf{1 0 . 2} \pm 1.28$ & $\mathbf{1 1 7} \pm 4.00$ & $\mathbf{3 1 5} \pm 11.8$ & $\mathbf{1 7 8} \pm 22.6$ & $122 \pm 3.80$ & $1046 \pm 33.1$ & $\mathbf{6 2 2} \pm 59.9$ & $174 \pm 3.44$ & $184 \pm 3.04$ & $\mathbf{8 1 . 4} \pm 9.54$ \\
\hline & $2001-2013$ & $0.016^{*}$ & $0.016^{*}$ & $0.016^{*}$ & 0.397 & $0.016^{*}$ & $0.016^{*}$ & 0.844 & 0.66 & 0.18 & $0.0047 * *$ \\
\hline
\end{tabular}

${ }^{1}$ cultivated crop: oilseed rape ${ }^{2}$ cultivated crop: clover-grass $^{3}$ cultivated crop: triticale

$T P F=$ triphenylformazan; $p-N P=$ p-nitrophenol; Bold letters: Mean values. Normal letters: \pm Standard error. Italic letters: $\mathrm{p}$-values for comparisons between the years: $p \leq 0.001^{* * *}, 0.001<p \leq 0.01^{* *}, 0.01<p \leq 0.05^{*}, p>0.05$ (not indicated). Paired $t$ test or paired Wilcoxon-rank-sum test (grassland)

relatively high $\mathrm{P}$ demand which is associated with $\mathrm{N}_{2}$ fixation, and as stated in the introduction, legume crops are known to mobilize less available $\mathrm{P}$ resources in soil. Therefore, the high labile P amounts in both arable systems in 2009 (Table 2) after growing red clover, might be explained by the active mobilization of the legumes and by a high P release during decomposition of plant residues (Talgre et al. 2014). The fact that P mobilizing species in crop rotations can enhance growth and $\mathrm{P}$ uptake in following crops is well described (e.g., Simpson et al. 2011).

Lower contents of the labile $\mathrm{P}$ fractions for grassland were found in 2013 in comparison to 2001 (no sampling in 2009) (Table 2). As mentioned above, the grassland soil had much higher initial soil $\mathrm{P}$ concentrations which make a significant decline under $\mathrm{P}$ budget deficits more probable.

The development of P supply in Trenthorst topsoil generally suggests that labile inorganic $\mathrm{P}$ fractions in soils will decrease over time with $\mathrm{P}$ budget deficits. However, the more stable inorganic $\mathrm{P}$ fractions (residual $\mathrm{P}, \mathrm{HCl}-\mathrm{P}$, and also total $\mathrm{P}$ ) remained almost unaffected in arable land over 12 years (Table 2). When appropriately addressed, they might be seen as potential buffer for future P release. Generally, mechanisms are known to address the utilization of this buffer by different crop species, microorganisms, and agricultural measures (Simpson et al. 2011). Nevertheless, the use of these mechanisms at the borderline of acceptable minimal contents of plantavailable $\mathrm{P}$ in soils has not been developed for practical agricultural management so far and they will depend very much on environmental factors.
The initial Porg contents in the grassland soils $\left(675 \mathrm{mg} \mathrm{kg}^{-1}\right)$ were about six times as high as in the arable soils (about $105 \mathrm{~kg} \mathrm{mg} \mathrm{kg}^{-1}$ ), and accounts for about $50 \%$ of the total P (in the arable fields only about 20\%) (Table 2). Although in tendency, the Porg contents in soil decreased in all systems during the study period, significantly lower contents were only found for the dairy arable system in 2013 when compared with 2009.

\subsection{Activities of enzymes in soil}

The microbial activities (activity of dehydrogenase) were about three to five times higher in the grassland soil than in the soil of the arable systems (Table 2), which is most probably related to the higher soil organic $\mathrm{C}$ contents (Table 1). It is well documented that an increase in soil organic matter enhances microbial biomass and the microbial activity of soils (Hupfauf et al. 2016). A higher microbial activity indicates a greater potential for mineralizing nutrients from organic compounds, which can replenish the labile inorganic soil $\mathrm{P}$ pools. Due to higher values, especially in grassland, we expected higher mobilization, e.g., from Porg. However, in our study, this replenishment could neither be found in grassland nor in arable fields. Quite the reverse, labile P forms were decreased in all systems after 12 years. In grassland, also the activity of dehydrogenase in soils decreased significantly which is in conjunction with the reduction of the soil organic $\mathrm{C}$ contents from 35 to $23 \mathrm{~g} \mathrm{~kg}^{-1}$ (Table 1). This view is supported by findings, that the structure and nature of $\mathrm{C}$ compounds can 
also have an effect of microbial processes in soil (Abraham and Chudek 2008). Plant litter is a primary source of food and energy for soil biota and its composition will therefore also have an effect on the microbial activity. Additionally, soil moisture and temperature are known to influence the microbial activity (Chen et al. 2003). However, as the activity of the dehydrogenase was relatively stable in the arable farming systems we do not believe that weather and soil conditions at sampling time were the major reasons for the decreased values in the grassland. But, quality changes in soil were visible in grassland by increased $\mathrm{C}: \mathrm{N}$ ratios and decreased total $\mathrm{N}$ concentrations compared to the beginning (Table 1). So, the decreasing trend in dehydrogenase activity in grassland might be related to decreasing organic matter input and of its changing quality due to lower fertilization level and lower plant growth with the introduction of organic farming in 2001. However, at the end of the study, the organic $\mathrm{C}$ contents in the grassland were still double that of the arable fields.

Looking at the phosphatases, the alkaline phosphatase is mainly produced by soil microorganisms, and the extent of its excretion should be coupled to the microbial activity (Albiach et al. 2000). Indeed, the alkaline phosphatase activity was found to be higher in the grassland than in the arable systems, although the differences were not as pronounced as for the microbial activities. Similarly, the activities of the acid phosphatase, which can be excreted by both crops and microorganisms, were also higher in the grassland soil. Relevant changes of the phosphatase activities from 2001 to 2013 were found only in the stockless arable system for the acid phosphatase (from 133 to $160 \mu \mathrm{g}$ P-NP g soil ${ }^{-1}$ ). Here, one should consider that the stockless arable system had the lowest initial activity of acid phosphatase. The values were increased compared to the values at the beginning of the study, probably caused by a broader range of crop species, especially the introduction of forage legumes (Table 1) with the conversion to organic farming. As the activities of the phosphatases tended to increase in all systems, this could also be related to the decrease of $\mathrm{P}(\mathrm{CAL})$ values and the other labile $\mathrm{P}$ forms which might have stimulated enzyme excretion. Whereas a negative correlation between soil-available $\mathrm{P}$ and phosphatase activity was described before, e.g., by Balota et al. (2011) a significant correlation between $\mathrm{P}(\mathrm{CAL})$ and phosphatase activity could not be derived from the data analyzed in this study.

\section{Conclusions}

The 12-year negative $\mathrm{P}$ budget reduced the level of plantavailable $\mathrm{P}(\mathrm{CAL})$ and labile inorganic $\mathrm{P}$ forms (Hedley fractionation) in soil of all organic farming systems. This showed that higher percentages of forage legumes and manure recycling in mixed arable crop rotations and grassland do not necessarily mitigate decreases of plant-available $\mathrm{P}$ contents in soil as compared to a stockless crop system. Nevertheless, $\mathrm{P}(\mathrm{CAL})$ contents remained above the threshold value for a sufficient $\mathrm{P}$ supply to plants. The question of whether P mobilization from soil reserves with further decreasing available $\mathrm{P}$ contents, e.g., by enhanced soil microbiological and rhizosphere effects, at this site will be more pronounced in the future, is still open. However, independent of the farming system, it will be necessary to find a site-specific fertilizer application rate to balance the P export with the harvested crops for the future.

Acknowledgements The soil analyses were partly supported by the BonaRes project InnoSoilPhos (No. 031A558, German Federal Ministry of Education and Research).

\section{References}

Abraham J, Chudek JA (2008) Studies on litter characterization using ${ }^{13} \mathrm{C}$ NMR and assessment of microbial activity in natural forest and plantation crops' (teak and rubber) soil ecosystems of Kerala, India. Plant Soil 303:265-273. doi:10.1007/s11104-007-9505-0

Achat DL, Bakker MR, Morel C (2009) Process-based assessment of phosphorus availability in a low phosphorus sorbing forest soil using isotopic dilution methods. Soil Sci Soc Am J 73(6):21312142. doi:10.2136/sssaj2009.0009

Albiach R, Canet R, Pomares F, Ingelmo F (2000) Microbial biomass content and enzymatic activities after the application of organic amendments to a horticultural soil. Bioresour Technol 75:43-48. doi:10.1016/S0960-8524(00)00030-4

Annaheim KE, Rufener C, Frossard E, Bünemann E (2013) Hydrolysis of organic phosphorus in soil water suspensions after addition of phosphatase enzymes. Biol Fertil Soils 49:1203-1213. doi:10.1007/ s00374-013-0819-1

Balota EL, Machineski O, Truber PV (2011) Soil enzyme activities under pig slurry addition and different tillage systems. Acta Sci Agron 33(4):729-737. doi:10.4025/actasciagron.v33i4.9816

Chen CR, Condron LM, Davis MR, Sherlock RR (2003) Seasonal changes in soil phosphorus and associated microbial properties under adjacent grassland and forest in New Zealand. For Ecol Manag 177(13):539-557. doi:10.1016/S0378-1127(02)00450-4

Cordell D, Drangert JO, and White S (2009) The story of phosphorus: global food security and food for thought. Glob Environ Change 19: 292-305. doi:10.1016/j.gloenvcha.2008.10.009

Dick CF, Dos-Santos ALA, Meyer-Fernandes JR (2011) Inorganic phosphate as an important regulator of phosphatases. Enzyme Res 2011: 1-7. doi:10.4061/2011/103980

Gosling P, Shepherd M (2005) Long-term changes in soil fertility in organic arable farming systems in England, with particular reference to phosphorus and potassium. Agric Ecosyst Environ 105:425-432. doi:10.1016/j.agee.2004.03.007

Güsewell S, Gessner MO (2009) N : P ratios influence litter decomposition and colonization by fungi and bacteria in microcosms. Funct Ecol 23(1):211-219. doi:10.1111/j.1365-2435.2008.01478.x

Hedley MJ, Stewart JWB, Chauhan BS (1982) Changes in inorganic and organic soil phosphorus fractions induced by cultivation practices and by laboratory incubations. Soil Sci Soc Am J 46:970-976. doi: 10.2136/sssaj1982.03615995004600050017x

Hinsinger P (2001) Bioavailability of soil inorganic P in the rhizosphere as affected by root-induced chemical changes: a review. Plant Soil 237:173-195. doi:10.1023/A:1013351617532 
Huang L, Bell RW, Dell B, Woodward J (2004) Rapid nitric acid digestion of plant material with an open-vessel microwave system. Commun Soil Sci Plan 35(3-4):427-440. doi:10.1081/CSS120029723

Hupfauf S, Bachmann S, Fernández-Delgado Juárez M, Insam H, Eichler-Löbermann B (2016) Biogas digestates affect soil P availability and microbial community composition. Sci Total Environm 542:1144-1154. doi:10.1016/j.scitotenv.2015.09.025

Jordan-Meille L, Rubæk GH, Ehlert PAI, Genot V, Hofman G, Goulding K, Recknagel J, Provolo G, Barraclough P (2012) An overview of fertilizer-P recommendations in Europe: soil testing, calibration and fertilizer recommendations. Soil Use Manage 28(4):419-435. doi: 10.1111/j.1475-2743.2012.00453.x

Kuchenbuch RO, Buczko U (2011) Re-visiting potassium-and phosphate-fertilizer responses in field experiments and soil-test interpretations by means of data mining. J Plant Nutr Soil Sci 174(2): 171-185. doi:10.1002/jpln.200900162

Li L, Li S, Sun J, Zhou L, Bao X, Zhang H, Zhang F (2007) Diversity enhances agricultural productivity via rhizosphere phosphorus facilitation on phosphorus-deficient soils. Proc Natl Acad Sci U S A 104: 11192-11196. doi:10.1073/pnas.0704591104

Manlay RJ, Feller C, Swift MJ (2007) Historical evolution of soil organic matter concepts and their relationships with the fertility and sustainability of cropping systems. Agric Ecosyst Environ 119(3-4):217233. doi:10.1016/j.agee.2006.07.011

Messiga AJ, Ziadi N, Jouany C, Virkajarvi P, Suomela R, Sinaj S, Belanger G, Stroia C, Morel C (2015) Soil test phosphorus and cumulative phosphorus budgets in fertilized grassland. Ambio 44(2):252-S262. doi:10.1007/s13280-015-0628-x

Nash DM, Haygarth PM, Turner BL, Condron LM, McDowell RW, Richardson AE, Watkins M, Heaven MW (2014) Using organic phosphorus to sustain pasture productivity: a perspective. Geoderma 221-222:11-19. doi:10.1016/j.geoderma.2013.12.004

Ohm M, Schüler M, Fystro G, Paulsen HM (2015) Redistribution of soil phosphorus from grassland to cropland in an organic dairy farm. Landbauforschung Ger 65(3-4):193-203. doi:10.3220/ Lbf1452867403000

Ohno T, Zibilske LM (1991) Determination of low concentrations of phosphorus in soil extracts using malachite green. Soil Sci Soc Am J 55:892895. doi:10.2136/sssaj1991.03615995005500030046x
Requejo M, Eichler-Löbermann B (2014) Organic and inorganic phosphorus forms in soil as affected by long-term application of organic amendments. Nutr Cycl Agroecosyst 100:245-255. doi:10.1007/ s10705-014-9642-9

Richardson AE, Lynch JP, Ryan PR, Delhaize E, Smith FA, Smith SE, Harvey PR, Ryan MH, Veneklaas EJ, Lambers H, Oberson A, Culvenor RA, Simpson RJ (2011) Plant and microbial strategies to improve the phosphorus efficiency of agriculture. Plant Soil 349(12):121-156. doi:10.1007/s11104-011-0950-4

Schüller H (1969) Die CAL-Methode, eine neue Methode zur Bestimmung des pflanzenverfügbaren Phosphates in Böden. Z Pflanzenernähr Bodenkd 123:48-63. doi:10.1002/jpln. 19691230106

Simpson RJ, Oberson A, Culvenor RA, Ryan MH, Veneklaas EJ, Lambers H, Lynch JP, Ryan PR, Delhaize E, Smith FA, Smith SE, Harvey PR, Richardson AE (2011) Strategies and agronomic interventions to improve the phosphorus-use efficiency of farming systems. Plant Soil 349(1-2):89-120. doi:10.1007/s11104-011-0880-1

Tabatabai MA, Bremner JM (1969) Use of p-nitrophenyl phosphate for assay of soil phosphatase activity. Soil Biol Bioch 1:301-307. doi: 10.1016/0038-0717(69)90012-1

Talgre L, Lauringson E, Roostalu H, Makke A (2014) Phosphorus and potassium release during decomposition of roots and shoots of green manure crops. Biol Agric Hortic 30(4):264-271. doi:10.1080/ 01448765.2014.953582

Thalmann A (1968) Zur Methodik der Bestimmung der Dehydrogenaseaktivität im Boden mittels Triphenyltetrazoliumchlorid (TTC). Landwirtsch Forsch 21:249-258

Tiessen H, Moir J, Carter M (1993) Characterization of available P by sequential extraction. In: Carter MR (ed) Soil sampling and methods of analysis. CRC, Boca Raton, pp 75-86

Tóth G, Guicharnaud R-A, Tóth B, Hermann T (2014) Phosphorus levels in croplands of the European Union with implications for $P$ fertilizer use. Eur J Agron 55:42-52. doi:10.1016/j.eja.2013.12.008

Tunney H, Csatho P, Ehlert P (2003) Approaches to calculating P balance at the field scale. J Plant Nutr Soil Sci 166:438-446. doi:10.1002/ jpln.200321153

Zhan X, Zhang L, Zhou B, Zhu P, Zhang S, Xu M (2015) Changes in Olsen phosphorus concentration and its response to phosphorus balance in black soils under different long-term fertilization patterns. PLoS One 10(7):e0131713. doi:10.1371/journal.pone.0131713 